\title{
THE USE OF $\alpha$-METHYL-D-GLUCOSIDE, A SYNTHETIC ANALOGUE OF MALTOSE, AS INDUCER OF AMYLASE BY ASPERGILLUS SP IN SOLID-STATE AND SUBMERGED FERMENTATIONS
}

\author{
Fabiana G. Moreira; Veridiana Lenartovicz; Cristina G.M. de Souza; Edivan P. Ramos; Rosane M. Peralta* \\ Departamento de Bioquímica, Universidade Estadual de Maringá, Maringá, PR, Brasil
}

Submitted: June 26, 2000; Returned to authors for corrections: October 16, 2000; Approved: January 18 , 2001

\begin{abstract}
The use of $\alpha$ methyl-D-glucoside ( $\alpha \mathrm{MG})$, a synthetic analogue of maltose, as carbon source and inducer of amylase synthesis to several species of Aspergillus was studied in submerged and solid-state fermentations. Among a group of ten species, A. tamarii, A. fumigatus and A. flavus were able to produce biomass and high specific amylolytic activity in submerged cultures containing $\alpha \mathrm{MG}$ as the only carbon source. In solid state fermentation, the enrichment of basal wheat bran or corn cob medium with $\alpha \mathrm{MG}$ increased up to 3 times the production of amylases. In both submerged and solid state fermentations, aMG was more effective inducer of amylases than maltose and starch.
\end{abstract}

Key words: amylase, Aspergillus, solid-state fermentation, submerged fermentation

\section{INTRODUCTION}

Many microorganisms, including bacteria, yeast and filamentous fungi are able to produce amylases (a term that refers here as $\alpha$-amylase, $\beta$-amylase and glucoamylase) and are among the most important enzymes in present day biotechnology $(8,16,17)$. Amongst the fungal amylases, those of species of Aspergillus such as A. niger, A. awamori and A. oryzae have received most attention because of their high productivity (20).

Fungal amylases can be produced using two main methods, solid state cultivation systems and submerged liquid cultivation systems. Although most research has used submerged culture, which allows the control of degree of aeration, $\mathrm{pH}$, temperature of the medium and other environmental factors required for the optimum growth of the microorganisms, solid state fermentation has gained renewed interest for the production of these enzymes in view of several economic and engineering advantages. This procedure has been often employed to produce amylases (16).

Besides starch and starchy materials, maltose and other maltooligosaccharides have been described as inducers of amylases in microorganisms $(5,11,14,18,19)$. However, in some cases, the supplementation of cultures with maltose does not ensure the production of high levels of amylases, because maltose is readily hydrolysed to glucose and the production of enzyme is negatively affected $(4,18,19)$. One of several experimental strategies used to overcome this type of problem is the enrichment of culture media with inert synthetic analogues of mono-, di- or oligosaccharides as gratuitous inducers. For example, a series of non-metabolizable alkyl- $\beta$-D-xylosides, especially methyl- $\beta$-D-xyloside ( $\beta \mathrm{MX}$ ) have been used to induce the production of xylanase more efficiently than xylan in many microorganisms $(3,10,23)$. Then, the purpose of this study was to investigate the use of $\alpha$ methyl-D-glucoside $(\alpha M G)$, a synthetic analogue of maltose, as substrate for growth and inducer of production of amylase by Aspergillus sp., in both submerged and solid state fermentation.

\section{MATERIALS AND METHODS}

\section{Microorganisms}

Ten species of Aspergilli were used in this work: A. glaucus, A. clavatus, A. ochraceus, A. oryzae, A. janus, A. niger, A. parasiticus, A. tamarii, A. fumigatus and $A$. flavus. They were cultivated on potato dextrose agar at $30^{\circ} \mathrm{C}$ for 5 days for spore production. The conidial suspensions were prepared by adding $10 \mathrm{ml}$ of sterilized water to slant cultures and the surface gently rubbed with a sterilized wire loop.

\footnotetext{
* Corresponding author. Mailing address: Departamento de Bioquímica, Universidade Estadual de Maringá, CEP 87020-900, Maringá, PR, Brasil.E-mail: rmperalta@ uem.br
} 


\section{Enzyme production in submerged fermentation (SF)}

For production of enzymes in SF, two different forms of culture were used. In the first, spores of each fungus species were inoculated in $250 \mathrm{ml}$ Erlenmeyer flasks containing $50 \mathrm{ml}$ of mineral medium (13) supplemented with glucose at $1 \%(\mathrm{w} / \mathrm{v})$. Incubation was carried out on an orbital shaker at $120 \mathrm{rpm}$ and $30^{\circ} \mathrm{C}$ for 3 days. The mycelia were then recovered by filtration, washed twice with distilled water and fractions of $1 \mathrm{~g}$ (wet weight) were transferred to the same medium with starch, maltose or $\alpha \mathrm{MG}$ at $1 \%(\mathrm{w} / \mathrm{v})$ as the carbon source. Flasks were harvested at periodic intervals, the contents filtered through filter paper and the mycelia dried to constant weight at $60^{\circ} \mathrm{C}$. The culture filtrates were analysed for amylase activity and substrate residual concentration. In the second form of culture spores of each fungus species were inoculated in $250 \mathrm{ml}$ Erlenmeyer flasks containing $50 \mathrm{ml}$ of mineral medium supplemented with starch, maltose or $\alpha \mathrm{MG}$ at $1 \%(\mathrm{w} / \mathrm{v})$ as the carbon source. The cultures were developed at $30^{\circ} \mathrm{C}$ on a rotary shaker at $120 \mathrm{rpm}$. At periodic intervals, the mycelia were removed from the media by filtration and the enzymatic activities and substrate residual concentration were analysed in the culture filtrates. In both cases, the results were expressed as the mean of at least three different cultures.

\section{Enzyme production in solid-state fermentation (SSF)}

For production of enzymes in SSF, the fungi were grown at $30^{\circ} \mathrm{C}$ in $250 \mathrm{ml}$ Erlenmeyer flasks containing $5 \mathrm{~g}$ of wheat bran or corn cob powder enriched or not with glucose, maltose, starch or $\alpha \mathrm{MG}$ at $1 \%$ (w/w). Vogel solution (13) was used to adjust the moisture content to $75 \%$. Dry weight of the substrate and moisture content were determined gravimetrically after drying samples at $60^{\circ} \mathrm{C}$. In order to extract the enzyme, $50 \mathrm{ml}$ of cold water was added and the mixtures were shaken for $30 \mathrm{~min}$ at $4^{\circ} \mathrm{C}$ and centrifuged. The supernatants were assayed for amylase. Results were expressed as the mean of at least three different cultures.

\section{Enzyme activity and other analytical methods}

Amylase activity (a term that refers here to $\alpha$-amylase plus $\beta$-amylase plus glucoamylase activities) was estimated by analysis of reducing sugars released during hydrolysis of $0.5 \%(\mathrm{w} / \mathrm{v})$ starch in $0.05 \mathrm{M}$ phosphate buffer, $\mathrm{pH} 6.0$, at $40^{\circ} \mathrm{C}$ by the dinitrosalicylic acid method (12). One unit of amylase activity was defined as the amount of enzyme that releases $1 \mu$ mol of reducing sugar as D-glucose per min under the assay conditions. Reducing sugar concentration was estimated using dinitrosalicylic acid reagent. Starch, maltose and extracellular $\alpha \mathrm{MG}$ concentrations were estimated using the anthrone reagent (9). Glucose concentration was determined by the glucose oxidase peroxidase method (2). The intracellular $\alpha \mathrm{MG}$ were extracted with ethanol (mycelia were boiled for $20 \mathrm{~min}$ in $70 \%$ ethanol) and the ethanolsoluble extracts were subjected to paper chromatography on Whatman $n^{\circ} 1$ paper in 1:5:3:3 benzene:butanol:pyridine:water, and developed with a silver nitrate reagent (22).

\section{Chemicals}

Starch, maltose, $\alpha \mathrm{MG}$ and glucose were obtained from Sigma Chemical Corp. (St. Louis, Mo). All other reagents were of analytical grade.

\section{RESULTS AND DISCUSSION}

The $\mathrm{pH}$ values of all cultures in this work were monitored and no significant difference among $\mathrm{pH}$ values were observed in the cultures supplemented with different sugars (data not shown). High levels of amylase were found in submerged culture filtrates with starch, maltose or starchy materials, while very low levels of amylase were detected in submerged culture filtrates with glucose, cellobiose, lactose or sucrose (data not shown). Thus, the amylases from Aspergillus sp are inductive enzymes. To examine whether $\alpha \mathrm{MG}$ was applicable to the amylase production as an available inducer, washed glucose-grown mycelia were transferred to media containing starch, maltose or $\alpha \mathrm{MG}$ at $1.0 \%$ as substrate (Fig. 1A). An effective induction by $\alpha \mathrm{MG}$, more efficient than starch and maltose induction, was found in A. flavus, A. tamarii and A. fumigatus, while no induction by $\alpha \mathrm{MG}$ was observed in the other seven species. The determination of residual concentrations of starch, maltose and $\alpha \mathrm{MG}$ in the culture filtrates, showed that $\alpha \mathrm{MG}$ was not consumed by A. glaucus, A. clavatus, A. ochraceus, A. oryzae, A. janus, $A$. niger and $A$. parasiticus, while the determination of residual $\alpha \mathrm{MG}$ in the culture filtrates of species induced by $\alpha \mathrm{MG}(A$. flavus, $A$. tamarii and $A$. fumigatus), indicated that more than $70 \%$ of $\alpha \mathrm{MG}$ was taken up by the cells (Fig. 1B). As some synthetic analogues of sugars have been described as non-metabolizable inducers $(3,15,23)$, the intracellular $\alpha \mathrm{MG}$ was extracted with ethanol and the ethanol-soluble extracts were subjected to paper chromatography. The experiment showed that $\alpha \mathrm{MG}$ was present, but did not accumulate inside the mycelia (data not shown). Thus, these three species of Aspergillus were apparently able to use $\alpha \mathrm{MG}$ as carbon source. To confirm this idea, spores of Aspergillus sp were inoculated into mineral medium containing $\alpha \mathrm{MG}$ as the only carbon source and the production of biomass by these cultures was compared with those obtained from starch and glucose cultures (Fig. 2). Three species, A. flavus, A. tamarii and A. fumigatus were able to produce biomass when $\alpha \mathrm{MG}$ was offered as the only carbon source. However, $\alpha \mathrm{MG}$ was consumed more slowly by the cells than starch and glucose. In fact, the residual starch and glucose concentrations in the culture filtrates were less than $5 \%$ after 4 days of cultivation, while 10 days were necessary for the cells to consume $90 \%$ of $\alpha \mathrm{MG}$ (data not shown).

The production of amylases in cultures using maltose and $\alpha \mathrm{MG}$ as the substrate was monitored daily (Fig. 3A-C). The residual concentration of the substrate in the maltose-culture filtrates was less than $10 \%$ after 3 days, while production of amylases by the three species was maximum in the 5-day-cultures. After a lag of 2 days, where apparently the cells did not take up any $\alpha \mathrm{MG}$, the residual concentration of this source decreased 

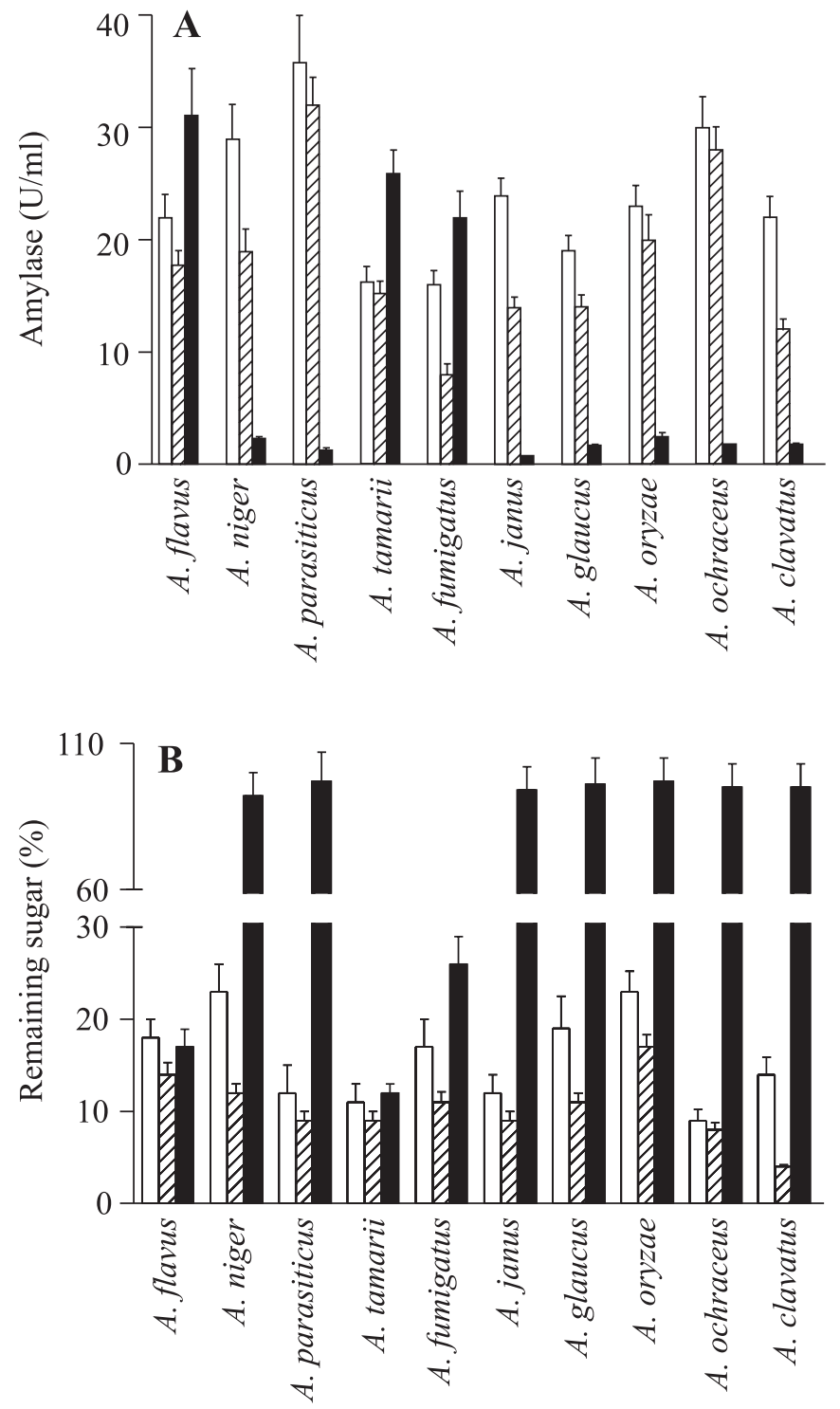

Figure 1. Production of amylases by Aspergillus sp. Washed glucose-grown cells were transferred to the inducing culture medium containing starch $(\square)$, maltose $(\mathbb{Z})$ or $\alpha M G(\square)$ at $1 \%(\mathrm{w} / \mathrm{v})$. The cultures were carried out at $30^{\circ} \mathrm{C}$ and $120 \mathrm{rpm}$. After 4 days, the levels of amylase (A) and the remaining inducer concentration (B) in the culture filtrates were determined. Error bars represent S.D. from the mean values.

slowly, and less than $10 \%$ was present in the culture filtrates after 10 days. The delay in the consumption of $\alpha M G$ suggests the requirement for a specific inducible transport system.

The inducer efficiency of some oligosaccharide synthetic analogues has been suggested before in submerged cultures of species of Aspergillus. The most used, $\beta$-methyl-xyloside, was a non-metabolizable inducer of xylanases from A. ochraceus (3)

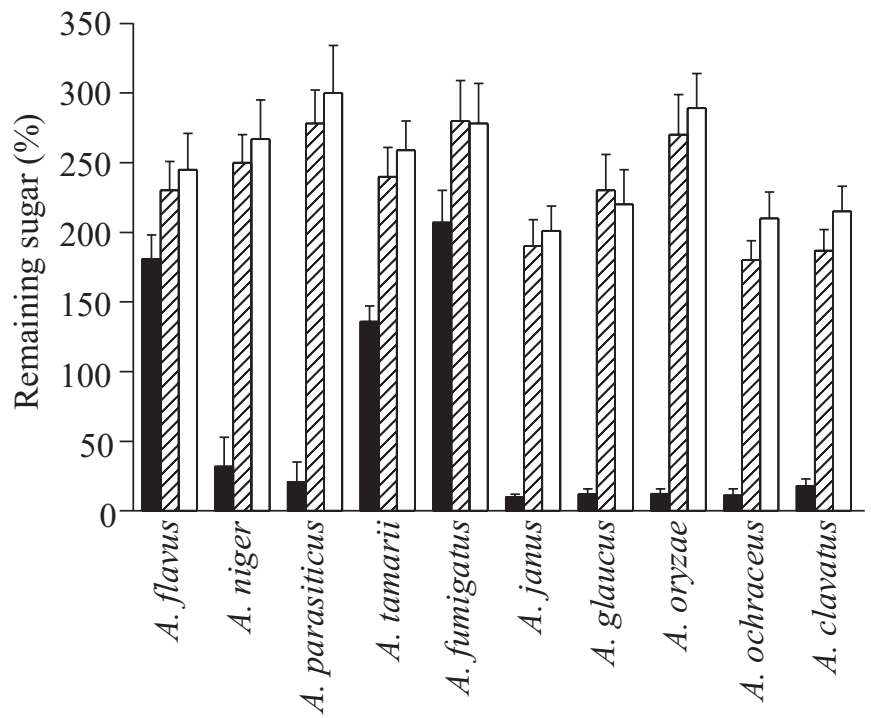

Figure 2. Production of biomass by Aspergillus sp. Spores of Aspergillus were inoculated in mineral medium supplemented with maltose $(\square)$, starch $(\mathbb{Z})$ or $\alpha \mathrm{MG}(\boldsymbol{\square})$ at $1 \%$ as the only carbon source and the cultures were developed at $30^{\circ} \mathrm{C}$ and 120 rpm. Starch and maltose cultures were carried out for five days and aMG cultures were carried out for 10 days. Error bars are S.D. from the mean values.

and A. sydowii (6) and a metabolizable inducer of xylanases from A. tamarii (21). The use of synthetic analogues of maltooligosaccharides is less frequent, but an efficient induction of amylases by $\alpha \mathrm{MG}$ has already been described in submerged cultures from A. fumigatus (7) and Aspergillus sp. K-27 (1).

To test the ability of $\alpha \mathrm{MG}$ to improve the production of amylases in solid-state fermentation, the fungi were cultivated under solidstate conditions using two different substrates: wheat bran (a starchy medium, where high levels of amylases are produced) and corn $\mathrm{cob}$ (very poor in starch and for this reason not adequate to produce amylases) enriched or not with $\alpha \mathrm{MG}$ at $1 \%$ (w/v) (Fig. 4A-B). The addition of $\alpha \mathrm{MG}$ increased about 1.5-2 times the production of amylase in wheat bran medium (Fig. 4A). The increase in the production of amylases can not be explained by the simple presence of an additional source of nutrients, considering that the addition of glucose, maltose, and starch did not result in a significant increase in the enzyme production. The inductive efficiency of $\alpha \mathrm{MG}$ was more evident from the results with corn cob cultures. Very low levels of amylase were produced using basal corn cob media, 15, 13 and $9 \mathrm{U} / \mathrm{g}$ substrate respectively to $A$. flavus, A. tamarii and $A$. fumigatus (Fig. 4B). The enrichment of the medium with starch or maltose increased about twice the production of amylase (40, 28 and $16 \mathrm{U} / \mathrm{g}$ substrate, respectively), while the addition of $\alpha \mathrm{MG}$ in the medium increased the production of amylases about four times or more (90, 70 and $60 \mathrm{U} / g$ substrate, respectively). 

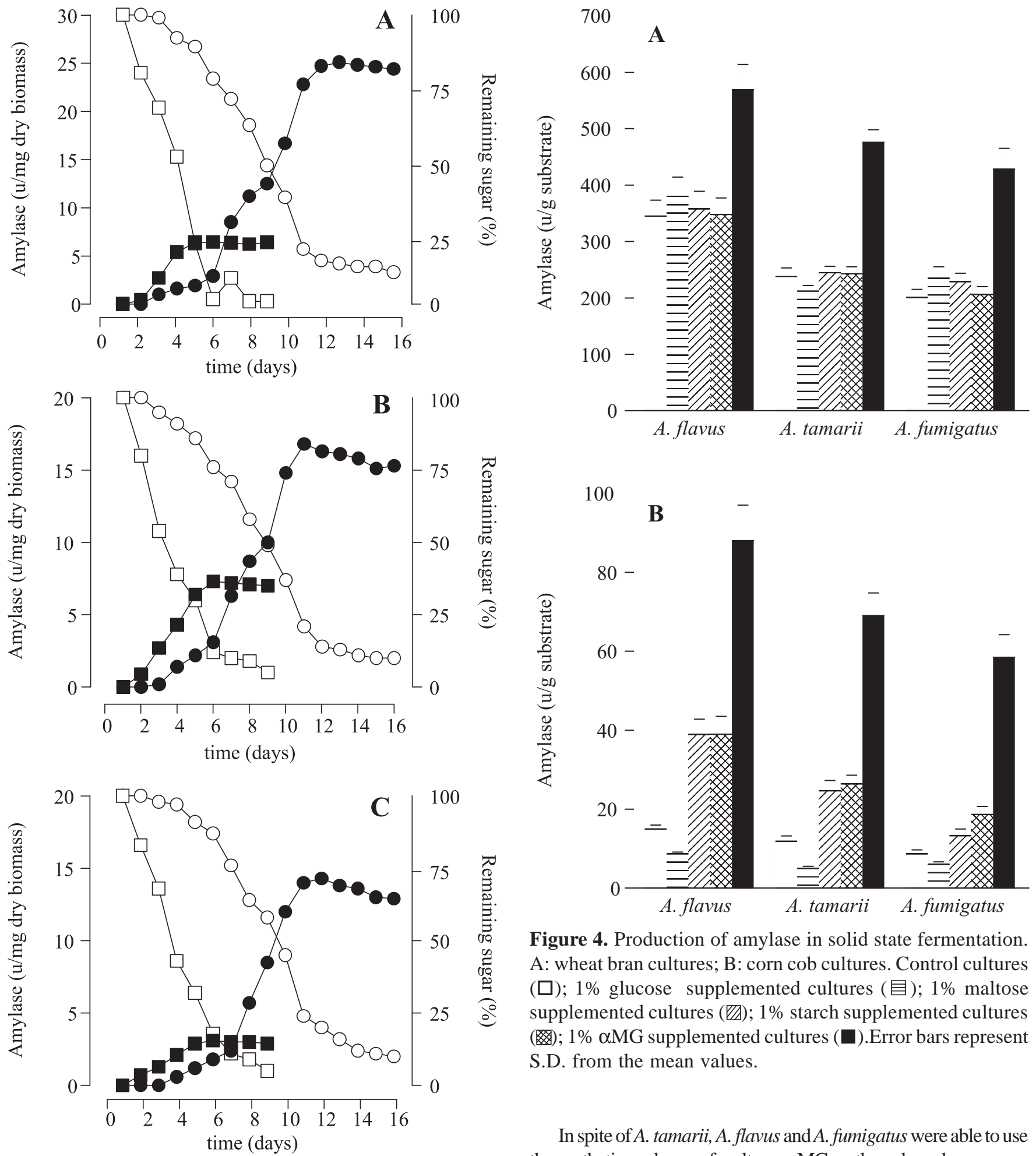

Figure 4. Production of amylase in solid state fermentation. A: wheat bran cultures; B: corn cob cultures. Control cultures (口); $1 \%$ glucose supplemented cultures (目); $1 \%$ maltose supplemented cultures ( $\mathbb{Q}$ ); $1 \%$ starch supplemented cultures ( $) ; 1 \% \alpha \mathrm{MG}$ supplemented cultures ( $(\boldsymbol{\square})$.Error bars represent S.D. from the mean values.

In spite of A. tamarii, A. flavus and A. fumigatus were able to use

Figure 3. Profile of amylase production by Aspergillus sp. A: A. flavus; B: A. tamarii; C: A. fumigatus. Amylase production in maltose cultures ( $\square$ ); amylase production in $\alpha \mathrm{MG}$ cultures (๑); maltose ( $\square$ ); $\alpha \mathrm{MG}(\mathrm{O})$. he synthetic analogue of maltose, $\alpha \mathrm{MG}$, as the only carbon source, the very large lag phase presented by the $\alpha \mathrm{MG}$ cultures when compared with maltose cultures, do not stimulate the use of $\alpha \mathrm{MG}$ as carbon source. However, the results presented in this paper support the conclusion that $\alpha \mathrm{MG}$ is an effective inductor of 
production of amylase by A. tamarii, A. flavus and A. fumigatus in both submerged and solid-state fermentation and may be added in the starchy cultures to increase the production of amylases. As solid state fermentation holds tremendous potential for the production of industrial enzymes $(16,17)$, the enrichment of conventional solid state media with synthetic inductor may be an attractive alternative to improve the efficiency of processes.

\section{ACKNOWLEDGMENTS}

This work was supported by the Conselho Nacional de Desenvolvimento Científico e Tecnológico (CNPq) and Universidade Estadual de Maringá. The authors are grateful to M.A.F. Costa and A.Chaves for their technical assistance.

\section{RESUMO}

\section{Uso de $\alpha$-metil-D-glucosídeo, um análogo sintético de maltose, como indutor de produção de amilases por Aspergillus sp em fermentação submersa e fermentação em estado sólido}

O uso de $\alpha$-metil-D-glucosídeo ( $\alpha \mathrm{MG})$, um análogo sintético de maltose, como fonte de carbono e indutor das amilases por Aspergillus sp., foi estudado em fermentação submersa e fermentação em estado sólido. De um grupo de dez espécies, $A$. tamarii, A. fumigatus e A. flavus foram capazes de produzir biomassa e alta atividade amilolítica em culturas submersas contendo $\alpha \mathrm{MG}$ como única fonte de carbono. Em fermentação em estado sólido, o enriquecimento do meio basal de farelo de trigo ou sabugo de milho com $\alpha \mathrm{MG}$ aumentou em 3 vezes a produção das amilases. Tanto em fermentação submersa quanto em fermentação em estado sólido, $\alpha \mathrm{MG}$ induziu mais eficientemente a produção de amilases que maltose e amido.

Palavras-chave: amilase, Aspergillus sp., fermentação em estado sólido, fermentação submersa

\section{REFERENCES}

1. Abe, J-I.; Bergmann, F.W.; Obata, K.; Hizukuri, S. Production of the rawstarch digesting amylase of Aspergillus sp. K-27. Appl. Microbiol. Biotechnol. 27:447-450, 1988.

2. Bergmeyer, H.U.; Bernt, E. D-glucose determination with glucose oxidase and isomerase. In: Methods of enzymatic analysis. ed. Bergmeyer, H.U. Verlag/Chimie/Academic Press, New York, 1974, p.1205-1212.
3. Biswas, S.R.; Mishra, A.K.; Nanda, G. Induction of xylanase in Aspergillus ochraceus. Folia Microbiol. 33: 355-359, 1988.

4. Brock, T.D.; Madigan, M.T.; Martinko, J.M.; Parker, J. Macromolecules and Molecular Genetics. In: Biology of Microorganisms, Prentice-Hall, Inc., New Jersey, 1994, p.170-173.

5. Busch, J.E.; Porter, E.G.; Stutzenberger, F.G. Induction of alpha-amylase by maltooligosacharides in Thermomonospora curvata. J. Appl. Microbiol., 82:669-676, 1997.

6. Gosh, M.; Nanda, G. Physiological studies on xylose induction and glucose repression of xylanolytic enzymes in Aspergillus sydowii MG 49. FEMS Microbiol. Lett. 117: 151-156, 1994.

7. Goto, C.E.; Barbosa, E.P.; Kistner, L.C.L.; Moreira, F.G.; Lenartovicz, V.; Peralta, R.M. Production of amylase by Aspergillus fumigatus utilizing $\alpha$ methyl-D-glucoside, a synthetic analogue of maltose, as substrate. FEMS Microbiol. Lett. 167: 139-143, 1998.

8. Guzman-Maldonado, H.; Paredes-Lopez, O. Amylolytic enzymes and products dereived from starch: a review. Crit. Rev. Food Sci. Nutrit., 35: 373-403, 1995

9. Herbert, D.; Phipps, P.J.; Strange, R.E. Chemical analysis of microbial cells In: Methods in Microbiology. Vol. 5B, Academic Press, New York, 1971, p.210-344.

10. Hrmová, M.; Biely, P.; Vrsanská, M. Cellulose and xylan-degrading enzymes of Aspergillus terreus and Aspergillus niger. Enz. Microbiol. Technol., 11: 610-616, 1989.

11. Ilori, M.O.; Amund, O.O.; Omidiji, O. Effect of carbon and nitrogens sources on glucoamylase production in Lactobacillus brevius. Folia Microbiol., 41:339-340, 1996.

12. Miller, G.L. Use of dinitrosalicylic acid reagent for determination of reducing sugar. Anal. Chem., 31: 426-428, 1959.

13. Montenecourt, B.S.; Eveileigh, D.E. Preparation of mutants of Trichoderma reesei with enhanced cellulase production. Appl. Environ. Microbiol., 34: 777-784, 1977

14. Morkeberg, R.; Carlsen, M.; Nielsen, J. Induction and repression of $\alpha$ amylase production in batch and continuos cultures of Aspergillus oryzae. Microbiology-UK, 141:2449-2454, 1995.

15. Murygina, V.P. Regulation of alpha-amylase biosynthesis in Bacillus diastaticus mutants with various levels of enzyme synthesis. Mikrobiologiia, 57: 734-739, 1988.

16. Pandey, A.; Nigam, P.; Soccol, C.R.; Soccol, V.T.; Singh, D. and Mohan, R. Advances in microbial amylases. Biotechnol. Appl. Biochem., 31:135-152, 2000.

17. Pandey, A.; Selvakumar, P.; Soccol, C.; Nigam, P. Solid state fermentation for the production of industrial enzymes. Curr. Science, 77: 149-162, 1999.

18. Ray, R.R.; Jana, S.C.; Nanda, G. Induction and catabolite repression in the biosynthesis of $\beta$-amylase by Bacillus megaterium B6. Biochem. Mol. Biol. Int., 38: 223-230, 1996.

19. Sadhukhan, R.K.; Roy, S.K.; Raha, S.K.; Manna, S.; Chakrabarty, S.L. Induction and regulation of $\alpha$-amylase synthesis in a cellulolytic thermophilic fungus Myceliophthora thermophila D14 (ATCC 48104). Ind. J. Exp. Biol., 30: 482-486, 1992.

20. Saha, B.C.; Zeikus, J.G. Microbial glucoamylases: biochemical and biotechnological features. Starch Staerke, 41: 57-64, 1989.

21. Simão, R.C.G.; Souza, C.G.M.; Peralta, R.M. The use of methyl- $\beta-D-$ xyloside as a substrate for xylanase production by Aspergillus tamarii. Can. J. Microbiol., 43: 56-60, 1997.

22. Trevelyàn, W.E.; Procter, D.P.; Harrison, J.G. Detection of sugars on paper chromatograms. Nature (London), 166: 444-445, 1950.

23. Yasui, T.; Nguyen, B.T.; Nakanishi, K. Inducers for xylanase production by Cryptococcus flavus. J. Ferment. Technol., 62: 353-359, 1984. 